\title{
THE MANAGEMENT OF CULTURE: PROFESSIONAL CHALLENGES OF MANAGING NARRATIVES AND BRANDS IN A CHANGING CULTURAL ENVIRONMENT.
}

\section{A GESTÃO DA CULTURA: DESAFIOS PROFISSIONAIS DA GESTÃO DE NARRATIVAS E DE MARCAS NUM AMBIENTE CULTURAL EM MUDANÇA.}

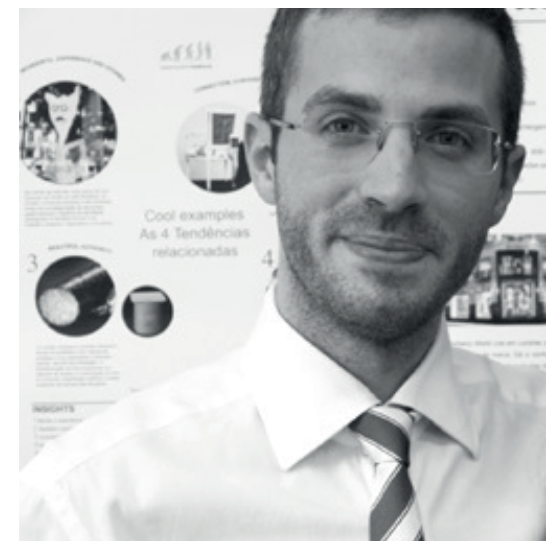

\section{Nelson Pinheiro Gomes}

Ph.D and Post-Doc. in Culture and Communication by the University of Lisbon.

Assistant Professor at the School of Arts and Humanities, University of Lisbon.

nelsonpinheiro@campus.ul.pt 


\section{ABSTRACT}

This paper explores the relations between culture, consumer behavior and management, introducing a new perspective for the study of cultural management, in order to activate better relationship strategies between brands and their audiences. The objective is to understand the instrumentalization of culture and behavior changes, resulting in a better creation and management of cultural symbols and narratives for brands. The ability to create and to imprint meanings in new products, services and pieces of communication requires a professional not only in the field of brand management, but also on the study of culture and emerging mindset and behavior trends. In this sense, this paper explores the role of this professional, the Chief Culture Officer (CCO), and how he/she can benefit from the application and the development of trends studies.

\section{KEYWORDS}

Culture; Trends; Cultural Branding; Chief Culture Officer.

\section{RESUMO}

Este artigo explora as relações entre cultura, comportamento de consumo e gestão, introduzindo uma nova perspetiva sobre o estudo da gestão da cultura, de modo a ativar melhores estratégias para o relacionamento entre as marcas e os seus públicos. O objetivo consiste em compreender a instrumentalização da cultura e das mudanças nos comportamentos, que resultam numa melhor gestão e criação de símbolos e de narrativas. A habilidade de criar e de imprimir significados em novos produtos, serviços e peças de comunicação requer um profissional capaz não apenas no campo da gestão de marcas, mas também no estudo da cultura e de tendências emergentes de mentalidade e de comportamento. Neste sentido, este artigo explora o papel deste profissional, o Chief Culture Officer (CCO), e como ele pode beneficiar-se da aplicação e do desenvolvimento dos estudos de tendências.

\section{PALAVRAS-CHAVE}

Cultura; Tendências; Branding Cultural; Chief Culture Officer.

\section{INTRODUCTION}

There are three main ways to interpret and understand the relations between culture and management. One of them has been long approached and developed and it is related to managing a business culture, or a brand culture. This 
is about your internal culture and how one projects it. It comes from within the organization to its exterior. The second notion, and the most explored when we talk about cultural management, dwells on the application of business concepts and practices in the cultural sector and even in the creative industries. This paper deals with the third notion. In sum, it is the potential of studying culture in order to better manage a business and a brand. This deals with understanding cultural shifts and changes and how that translates into new desires and behaviors. In this sense, this paper explores the disciplines of cultural management and consumer culture in a broader approach to brand culture ${ }^{1}$ and business management.

Regarding the method, this paper works as a conceptual framework based on literature review, in order to provide the basis for future applied research in the form of field experimentation and case studies. This work underlines the growing importance of studying the cultural context and how it should become a normal practice within businesses, going beyond the regular practices of market studies and focusing on cultural shifts and new consumer desires hat rise from emerging mindsets. Also, it is important to review the concept and the profile of the Chief Culture Officer (CCO), as proposed by Grant McCracken (2011), since it can incorporate many of the skills associated with the trends analyst.

This concept unveils a gap within the scope of business professions and skills that this papers aims to address. Grant McCracken has maintained a position as a critic of the coolhunter and trends analyst. In fact, many of these professionals are not well prepared and the area is still new, focusing more on what is ephemeral. However, this paper suggests that proper coolhunting and trends analysis skills can be very useful for the CCO and can help him to become a better professional at cultural analysis and management. This will be accomplished by presenting articulations between concepts from the main perspectives of consumer culture and cultural trends studies. For these purposes, it shall be given a special attention to the works of Grant McCracken (2011), Douglas Holt (2004), Michael Solomon (1999), and Henrik Vejlgaard (2008), and to the development of trends studies in Portugal and their contribution to cultural analysis (GOMES \& FRANCISCO, 2013).

$1 \quad$ This division of the concept of culture within an organization, between internal culture and the external cultural context is a topic to consider. Like Tilde Heding, Charlotte F. Knudtzen and Mogens Bjerre suggest, "brand culture is a term that has been increasingly used over the last few years. It sometimes refers to the organizational culture of the brand and sometimes to the brand as part of the broader cultural landscape" (HEDING et al, 2009, p. 11). 
The paper begins to explore the relations between culture, trends and the zeitgeist, in order to understand cultural shifts and how they can change the way companies operate. After this, it is important to understand how these changes affect the consumer culture and what is their role in brand management and consumer relations, in order to introduce the Chief Culture Officer as the expert that can guide a brand and a company within these ever more elusive social changes, generating innovative and more informed strategies.

\section{THE ROLE OF CULTURE IN MANAGEMENT:ZEITGEIST, TRENDS AND BRANDS}

In a fast changing world, whose time and zeitgeist can be defined as a liquid modernity (BAUMAN, 2000), companies need to keep up with cultural changes and the emergence of new mindsets and behavior patterns. This paradigm underlines a new manifestation of modernity that is more liquid and fluid. Barriers like space, or even time, are being shattered by technology and globalization is a changing structure where the future imposes in some ways to the present and society is always mindful of the next moment. Also, these are times where everything needs to be better and faster, where consumers are more demanding. It is difficult to understand these new social realities and dynamics, so it is necessary to look forward to new disciplines and connections between fields, concepts and methods.

We are seeing the rise of new fields of knowledge like Trends Studies (GOMES and FRANCISCO, 2013) - the study of patterns of change in social behavior, culture and mindsets - and the consolidation of others like Future Studies, but the consumer is still a mystery to many businessmen. Taste and consumer behavior patterns change so much and so fast, that one needs to be focused only on the observation and study of such changes, having a big task to perform. To allow the consumer and the public to become strangers is to lose their attention and interest. As such, companies, especially big ones, need to have experts with a keen eye and the depth of knowledge to understand new shifts, desires and perceptions on consumer culture. Trends analysis helps with this problem, by underlining emerging cultural patterns and providing a wide perspective on consumer behaviors.

A trend, in this sense, can be defined from different perspectives. For Martin Raymond, a style represents something new and a difference, while a trend shows the direction to which that difference travels (RAYMOND, 2010, p. 1314). It is important to add and underline that a trend represents a cultural and 
behavioral change, a shift in mindsets that can be seen through small seeds and manifestations of creativity and innovation in the sociocultural scenarios. The current times demand for the ability to identify these changes and to manage these cultural shifts. In a sense, it is a form of cultural management. William Higham suggests that:

The speed of consumer and product change, the blurring of traditional demographic boundaries, the growing power of the consumer and the nature of globalism are all making trend determination a necessity. Trends can help companies make sense of their market in time of change (Higham, 2009, p. 17).

Cultural studies, as developed from the Birmingham School, give us a good perception on the relations of power in culture, among other insights, but like anthropology or sociology, it is not directly oriented towards cultural management, in the sense of applying cultural analysis to management. Trends studies, as an emerging field, can help to articulate cultural analysis with cultural management, adding a new perspective to the management of brands, and even cultural branding (a concept that will be discussed further in this paper).

Trends studies focus their attention on the study of mindsets and emerging cultural shifts. It searches for the creative seeds and signals of innovation in daily life. Those innovations may be found in new products, services, communication pieces, and all cultural artifacts and manifestations that show an engaging, alluring, cutting edge and inspiring nature with potential for replication. By observing, registering and comparing these seeds, the trends analyst can begin to map changes in consumer behavior and mindsets, while they are still growing, allowing for the generation of insights that can help brands to manage change and become more prepared to new consumer needs and behaviors (see GOMES, 2016). In this way, trends studies can navigate between cultural analysis and consumer culture. As Henrik Vejlgaard (2008) suggests, trends are created by people, so trendspotting is possible because the key element in the analysis of any trend is to observe what trendsetters do and how they generate new signifying practices. In other words, trends studies allows to identify small changes in the zeitgeist that can be insightful for the creation of new or better products, as well as communication and engagement strategies.

The field of trends studies articulates several disciplines, using perspectives and practices from anthropology, sociology and business administration, such as ethnography and market research, among others. One of its major disciplines is coolhunting. Although it is a growing practice, real coolhunters are still rare, since most lack formal training or experience. Coolhunting implies the search 
for innovative and creative cultural manifestations that can be registered and analyzed, in order to see patterns and to generate insights that can be replicated. Each observation must imply the description of the manifestation, its context and visual record, as well as the reason why it is attractive, inspiring and with replication potential. This analysis, empirically developed by Carl Rohde, will not only allow to foresee, due to the comparison with other manifestations, cultural changes that are emerging (GOMES and FRANCISCO, 2013), but will also act as an important benchmark analysis for the generation of innovation. All these insights can be translated into management strategies.

When we articulate the many observed and registered cultural manifestations with other quantitative and qualitative data (statistical data; interviews and questionnaire results; among others), it is possible to better understand changes in the zeitgeist and consumer culture. It will also show us major mindset trends and societal topics - or zeitgeist topics - that guide daily life activities and beliefs.

\section{CONSUMER CULTURE: A BRIDGE BETWEEN CULTURE AND MANAGEMENT}

Jürgen Habermas stated that "the public sphere in the world of letters was replaced by the pseudo-public or sham-private world of culture consumption" (HABERMAS, 1991, p. 160). Consumer society as we know it has no specific birth date. She was idealized and came to be based on mindset alterations and new group and individual needs, considering the mutations in social structures and processes. Roberta Sassateli adds:

The development of places which made a large quantity of goods visible to the whole population that the connection between personal identity, commerce and objects became central to a growing number of people, and it was thanks to a thematization of consumption as a meaningful social activity that the changing patterns of consumption gave way to consumer society as much. This was accompanied by the rise of the "consumer" as a powerful social identity, called into life and engaged by a host of discourses and situated strategies of enticement which both democratized desires and standardized them (Sassateli, 2007, p. 45). However, the major question revolves around the relations between objects/ artifacts, consumption and group/individual identities. As Daragh O'Reilly suggests, consumption is where meaning is produced (O'REILLY, 2005). When consumption became a common practice, associated with a capitalist system, the act of consumption starts to arise as a social activity that regulates a large part of the social life and identity constructions. Consumer culture becomes 
an important reflection of the zeitgeist and the invisible processes that go behind social constructions.

Individualism and collectivism give place to several movements and trends related to consumer culture. Such culture promotes the construction of identity narratives that help to consolidate lifestyle patterns. Today, personalization is one of the strongest patterns present in society, working as a social construct at the level of individualism. In turn, the emergence of youth cultures in the second half of the 20th century, as a support to alternative currents and to what would become "pop" culture, represented a revolution in the conventions of style and identity. In such cases, youth acted as a powerful change agent and mindset shift, making possible new consumer behaviors. Today, youth still represents an important role in the dissemination of new mindsets and in the adoption of its objects/artifacts and manifestations. In fact, it has an even bigger role with new digital channels and forms of cultural dissemination and consumption.

Prescribers are cultural agents and intermediaries that influence style and promote changes in consumer culture. They have an important symbolic capital that is capable of appealing to several groups. However, it is also necessary to understand the predisposition of individuals, and groups, faced with objects and the way in which they are willing to interact, create, modify or assimilate symbols and narratives. As Roberta Sassateli underlines, the first sociologists to concern themselves with consumption identified the positional logic as the main rationale. From this point of view, consumers are interested in getting and using objects, which can serve as symbols of status (SASSATELI, 2007). These symbols of status, or also of cool (MCCRACKEN, 2011), are negotiated among individuals, groups and brands, creating the objects of trends (not to be confused with the cultural patterns to which they are associated). Narratives are the symbolic constructions that are created in order to better promote these symbols and associations and they must be culturally pertinent.

Like Soren Askegaard and Dannie Kjeldgaard suggest, traditionally, the study of the relations between marketing and culture has been focusing on understanding and predicting problems that may arise due to cultural relativism, meaning the cultural differences between each space (ASKERGAARD \& KJELDGAARD, 2002). In other words, it inquires about the impact and the result of marketing strategies in each cultural space. However, the development of globalization puts these visions into question, since professionals must take into account that all production and strategies are created upon social conventions and cultural 
narratives that should be properly interpreted by the consumers, or audiences. Douglas Holt and Cameron Douglas add the following:

All mass-cultural expressions - whether a film or a retail store design or packaging graphics - rely on elements for which the meaning has been well established historically in the culture. It would be impossible to compose an expression from scratch, because, without no historic conventions to fall back upon, each and every element in the composition would have to be defined for the audience in a way that would allow for the proper interpretation. Cultural codes provide a shorthand for consumers, allowing them easily to understand and experience the intended meanings. (Holt \& douglas, 2010, p. 175)

With the cultural shifts mentioned in the former chapter, come new socialization structures and new processes of communication. From these, new power relations and prescribers begin to emerge and solidify their position (from bloggers, to youtubers and new young voices). This also leads to a greater pluralization of consumer artifacts and practices in a constant process of cultural adaptation and reconstruction that longs for the cool status and symbolism. Consumer culture is practiced and it is constituted by rituals and symbolic associations. As Pierre Bourdieu stated, it is a question of education and taste that relates to a sense of distinction and belonging (BOURDIEU, 2006). However, first of all, it is a matter of mindsets and ideas that propagate from brain to brain through mimesis and cultural contamination from individual to individual (DAWKINS, 2006).

Michael Solomon also suggests that it is quite common for mainstream culture to modify symbols identified with "cutting-edge" subcultures and present these to a larger audience. As this occurs, these cultural products undergo a process of cooptation, by which their original meanings are transformed by outsiders (SOLOMON, 1999, p. 523). This a way to disseminate associations and ideas, where symbols are constantly reconstructed and new meanings are associated and created, generating a new vision and a new practice. Only after a behavior spreads and becomes a social convention, a trend, we begin to see the visible representations and practices of consumer culture and new mindsets.

Eric Arnould and Craig J. Thompson see consumer culture theory as a field that articulates several disciplines and areas, confirming our position and statements: CCT [consumer culture theory] explores the heterogeneous distribution of meanings and the multiplicity of overlapping cultural groupings that exist within the broader sociohistoric frame of globalization and market capitalism. Thus, consumer culture denotes a social arrangement in which the relations between 
lived culture and social resources, and between meaningful ways of life and the symbolic and material resources on which they depend, are mediated through markets (ARNOULD and THOMPSON, 2005, p. 869).

It is important to have in mind that consumer culture implies the consumption of artifacts but also narratives, experiences and others. Today, we consume mainly on a symbolic level that works with our plural identities. In this sense, it is important to analyze produced images and texts that guide our perceptions, which are negotiated in turn by individuals and group members to create our social code. Marketing both produces and uses imagery and ideas, in order to generate positive responses and engagement. Sometimes, narratives are tested and fail, but when they work, they represent an added value for the brand. However, it must be understood that it is the general culture that approves or dismisses the brands practices, according to what are the current mindsets and major trends. Recently, consumers have been empowered and they are now an important part in the co-creation and affirmation of symbolic meanings associated in products, services, adverts, and others, because they are an increasingly intrinsic part in the definition of their own lifestyles. As Soren Askegaard and Dannie Kjeldgaard state:

The essence of reflexive culture is that it produces and sustains new cultural identities through consumption of marketized and commodified cultural forms [...] Thus, the situational and often ritualized performance of reflexive cultural identities becomes a critical mechanism of ethnic boundary formation and maintenance (ASKERGAARD and KJELDGAARD, 2002, p. 15).

Consumer culture represents choices between artifacts and narratives. The consumer, under a specific cultural set, chooses what and how to consume. A business manager and a marketer must understand that a brand must be able to adapt and represent culture and it must manage its practices and coded symbolisms. More than managing internal culture, this is about managing new cultural manifestations and orientations, or trends, in order for the consumer to experience and identify himself with what he is consuming. As Michael Solomon suggests, consumption choices cannot be understood without considering the cultural context in which they are made, since culture is the "lens" through which people view products (SOLOMON, 1999).

Grant McCracken adds that the system that creates consumer goods is an entirely cultural enterprise (MCCRACKEN, 1988). This brings considerations that help to understand that consumer culture is shaped by individuals and cultural shifts that are visible through the expression of trends associated with objects 
and behaviors. It is a way to encode meanings that reflect choices of lifestyle. These meanings are used in cultural and social contexts and they bind individual and group actions. The Chief Culture Officer is the professional capable of reading culture and cultural shifts, as well as trends, applying cultural insights into brands, narratives, services and products, amongst other cultural artifacts.

\section{THE CHIEF CULTURE OFFICER: MANAGING BRANDS AND CULTURE}

The Chief Culture Officer (CCO), a culture and trends expert, is a professional prepared to assist businesses in understanding who is the new consumer and how to create and communicate for him/her. This paper develops the profile of this expert, as an individual that can articulate cultural analysis with trends studies and consumer culture, producing insights to guide brand strategies and communication.

Grant McCracken (2011), anthropologist and specialist in the frontier where culture is articulated with management and consumer behavior, states in his work that the success of companies and brands in the current world is dependent on their ability to understand culture, urban tribes and emerging mindsets. For such, the author suggests the need to create this new professional, the Chief Culture Officer, capable of combining cultural sociology with management sciences. He could prevent certain strategic mistakes that brands have been committing in the past years. The author begins his work by stating:

Levi Strauss, the jeans and apparel maker, misses hip-hop. The penalty: \$1 billion. Quaker pays too much for Snapple. The penalty: $\$ 1.4$ billion. Facebook claims 7 billion photos as its own. Embarrassment and recantation follow. These corporations, like most, were bad at reading culture. And it cost them dearly. By culture, I don't mean corporate culture. And I don't mean "high culture", the world of refined taste. By culture, I mean outside the corporate, the body of ideas, emotions, and activities that make up the life of the consumer (MCCRACKEN, 2011, p. 1).

The CCO is able to see and understand the cultural map as a whole (MCCRACKEN, 2011). For him, fads and fashion are only indicators of fast culture and ephemeral desires, but they are still important to understand major patterns as seeds of what might be to come. This professional understands the cultural map as an integrated system and this is what sets him apart from a marketer, a sociologist or a market analyst. He sees the social order as the global and integrated system, which includes the structure (the mentality), the process and the 
object. Also, the structure becomes a synonym for the system in the sense that it integrates simultaneously both the processes and the objects that make her perceptible in the visible plain of culture.

To see the structured order, or system - all the mindsets, their processes and their objects - is to have a clearer view on how society is changing and what is bubbling as new, cool and emergent. These signs can be applied into strategy and the development of new proposals. This is consumer behavior analysis on a deeper cultural level and with a wider scope of analysis. It is a difficult assignment and it is impossible to accurately predict the future behaviors. However, as Zygmunt Bauman suggests, in a completely deprived state of order (structure), no amount of data will be enough to foresee a new sequence of events, but structure implies a differentiation of real probabilities among conceivable theoretical states and future states of a structured totality are predictable (BAUMAN, 2012).

If a small or medium sized enterprise needs to know its consumer and his/her current desires, that arise as a result of emerging mindsets, this is even more important for multinationals and other big companies. As Grant McCracken (2011, p.1) suggests, "when there's $\$ 1.4$ billion at stake, it needs a Chief Culture Officer". When we talk about brands with big impact narratives, it is important to properly consider changes on mindsets and behaviors. In this sense, there is an interest and an attempt to create relations with the audience in a sociocultural and economic space, which justifies the affirmation that all big brands are cultural strategies:

Culture matters for reasons good and bad. First, it is the place to discover advantage, opportunity, and innovation. The Four Seasons, Patagonia, Starbucks, Nike, Red bull, Target, Method Soap - each is culture play. Each found value in culture. [...] Without a working knowledge of culture, the corporation lives in a perpetual state of surprise, waiting for the next big storm to hit. Without a CCO, the corporation has no way to perform this crucial peace of threat assessment (McCracken, 2011, p. 2).

Daragh O'Reilly (2005) goes so far as to suggest that brands are symbolic articulators of production and consumption. In this sense, all brands are representational texts, and are socially, not merely managerially, constructed. The brand, as a symbolic representation that is constructed moves within consumer culture and between increasingly liquid structures that provoke a sense of constant surprise within corporations and the need for constant update and reflection. Cultural Branding (see HOLT, 2004) deals with this relation between brands and 
the cultural context, being inspired by the perspectives of cultural studies. Regarding this approach, Tilde Heding, Charlotte F. Knudtzen and Mogens Bjerre underline that the "literature deals with the way marketers can use cultural forces to build strong brands and what brands and branding do to culture. It is consumer culture rather than the individual consumer that is researched in the cultural approach" (HEDING et al., 2009, p. 209). In this sense, the brand is no longer the only center of attention and becomes an entity that must deconstruct the cultural shifts and social dynamics that surround her. Even big and strong brands like Prada have been suffering from very strong and fast cultural shifts. As Zygmunt Bauman (2000) refers, we are seeing an increasing fluidity of time, space, family, economy and other former strong social structures. However, it is not only structures that are suffering from this liquidity and fluidity, but also the communication processes that regulate social interactions and the big systems that articulate artifacts, processes and structures.

The CCO has the increasing responsibility to have a wider and global perception of the cultural set and its trends and changes, just like Grant McCracken underlines, being capable to distinguish between fads and fashions and their depts (MCCRACKEN, 2011, p. 2). Wherever to the culture shifts and goes, so must the strategy and business practices follow. McCracken adds that without the CCO, a business is always vulnerable to the next fashion, like the "viral", widgets, web 2.0 and others. To him, a company cannot be administered according to the idea of the moment (MCCRACKEN, 2011). Macro trends represent slow culture and are stronger cultural patterns that can give more stable insights into the future of consumer culture and for the generation of innovation. Since macro trends represent mindset structures with a strong cultural density - they affect a large number of symbols and signifying practices -, their changes can be less visible and they are more resistant to ephemeral elements. However, to understand changes at a macro level gives a strategic edge to the analyst and allows for time to adapt.

The CCO can help companies to tap into emergent cultural shifts and manifestations (from artefacts to rituals), providing the means for the creation of what Douglas Holt and Cameron Douglas named "cultural innovation" (HOLT and CAMERON, 2010), which occurs when a brand delivers an innovative cultural expression. The authors add that to understand cultural innovation, one needs first to understand the central role of cultural expressions in creating customer value (HOLT and CAMERON, 2010). This justifies a passing from abstract expressions to cultural expressions (HOLT, 2004), where institutional 
narratives become more complex and in tune with cultural context. This is why the role and skills of the Chief Culture Officer are more complex than those of the regular brand manager. He must be able to understand cultural shifts and trends and produce the insights for cultural innovation. This does not mean, however, that a brand manager cannot act as a CCO, if he develops the cultural analysis skills associated.

The CCO must have a global knowledge of culture, or as broad and insightful as possible. He cannot stay fixed on a specific area, as well as personal experiences, comfort zones and preferences (MCCRACKEN, 2011, p.14). It is necessary to make an effort to explore underground and emerging movements as well as different audiences and sets, since their study can generate insights for innovation. The creative process can be facilitated by joining different ideas from different contexts. But it is important to have in mind that it is possible to transfer innovation from one sector to another or the idea behind it.

The CCO can articulate these different seeds of innovation and create the basis for a strategy that responds to the needs of the brand audience(s). In a recent article, Richard Daddi suggested that culture acts as the central nervous system of any business, influencing every activity and decision. Purpose and values, capabilities and how they are delivered, relationships, costs, revenues, and every other critical component of the business architecture are informed by culture (DADDI, 2012). It falls to the Chief Culture Officer the task of acting as liaison between culture, and the general business and brand DNA. He connects the other managers with culture and guides strategic decision making, according to his analysis of cultural shifts.

The Chief Culture Officer is capable of combining the skills and tasks that are expected from a cultural analyst and a trends analyst, in close articulation with business strategy and marketing. He should have a good understanding of business models and practices, since he must articulate management and culture to improve business opportunities. The CCO is the professional that can create an informed bridge between the market, the consumers, the emergent culture, businesses and brands. In a world in constant and growing change, this individual dedicated to the observation of societal changes and the way these are evolving is of importance in the definition of a long-term strategy. By adding coolhunting and trends analysis skills to the former CCO profile, he becomes more proficient in cultural analysis. The following list presents a set of disciplines that can be developed by the CCO:

Trends Archeology. The discipline of trends studies that allows to understand what drivers promoted cultural change and how people react to certain ele- 
ments and stimuli. Although it is impossible to replicate a specific sociocultural context, this historic perspective gives the CCO insights on how audiences react and how trends emerge. By analyzing trends objects in the past and their specific cultural context, it is possible to understand the drivers that promoted change and how social groups responded to them. This practice is very important to understand social dynamics and to create scenarios for trends evolution. Although there is a pressure to look only to the future, the study of trends history - looking at the past and the present - is the first step to prepare any strategy and concept.

Coolhunting. This was the first specific discipline of trends studies and it is still one of its most famous methods to observe and identify trends. In the Dutch and Portuguese vision of trends studies, coolhunting consists on a qualitative field research method - both online and mainly in the urban space - that searches for seeds and manifestations of innovation and creativity that are attractive to one or more groups and that have the potential to replicate as ideas and benchmarks, inspiring innovation. These manifestations represent the first signs of cultural and behavioral shifts that, when analyzed over a long period of time and compared with other qualitative and quantitative data, provide insights that allow both to identify and follow trends, as well as generate innovation. The seeds that are observed and analyzed on the process of coolhunting are the visible aspect of trends - of the mindset structures. The mindsets, processes and dynamics behind those seeds are the invisible aspects that must be deciphered and analyzed to generate innovation insights.

Trendspotting and Trendwatching. Trendspotting, or the identification of trends, and trendwatching, which is the study of how trends evolve and impact consumer culture, can help to identify the major topics of the spirit of the time and compose a general picture of the zeitgeist and macro mindset trends, whose insights can be applied in management and strategy. While coolhunting provides the objects of analysis and trends archeology historically contextualizes the patterns under study, it is trendspotting and trendwatching exercises that identify trends and map their DNA.

When the CCO is able to articulate these different tools of cultural analysis, he can better understand how consumer behavior patterns are evolving and what where the tipping points for the emergence of certain successful products, services, styles and symbols. This knowledge gives an edge, regarding the competition and allows time for a business to adapt to new changes. Although trends studies are very focused on the study of fast culture, or cool culture, they also 
dwell, as we already discussed, on slow culture ${ }^{2}$ and macro mindset trends that exist for a long period of time. Cool culture jumps (MCCRACKEN, 2011) from artifact to artifact and from group to group, but the mindset that originates that cultural manifestation is more stable and the CCO must understand it. This underlines the need to cross fast culture with slow culture analysis. The objective is to generate insights that can be applied in the creation of something pertinent that can both appeal to social conventions, but if necessary with an edge that makes it stand out and become attractive.

The Portuguese perspective on trends studies focuses on the need to dwell on the complexity of macro mindsets, structures and trends that are more solid and complex, in order to understand emerging behaviors. However, since we live in a more liquid world, even macro mindset trends suffer changes and show them through different manifestations and cultural artifacts. That is why the Chief Culture Officer must be always on the lookout for these subtle changes that can transform consumer culture and generate new behaviors and business innovation.

\section{DISCUSSION}

The management of culture is a developing discipline that is showing increasing potential on a transdisciplinary level, helping to articulate cultural studies with management and with other fields, like trends studies. Although the relation between culture and management has been focusing on the business and brand culture, or in the normal cultural management perspective of integrating business models and practices in the cultural sector, there is a new perspective on the management of culture. Based on the proposal of Grant McCracken for the creation of the Chief Culture Officer (CCO) professional position, we showed that it is important to explore the path of studying culture to generate informed insights for better business strategies and practices. This is a new way to manage culture. In order words, it manages cultural shifts and changes, understanding new mindsets and cultural trends, by addressing them with new products, services, communication pieces, brand narratives and what a business and a brand need to do to adapt to new cultural behaviors. In this sense, the proposal of Grant McCracken for the CCO goes along the line the ideas of Douglas Holt (2004) regarding cultural branding, cultural strategy and the importance to generate cultural and innovative expressions.

2 Grant McCracken worked on the concepts of "fast" and "slow" culture while explaining the role of the Chief Culture Officer (MCCRACKEN, 2011). 
Following these relations, one of the major difficulties resided on the links between the brand manager and the Chief Culture Officer, since they seem to overlap on many aspects. In fact, they share numerous skills and roles, however, the CCO dwells more deeply on matters of diagnostic and sociocultural analysis to develop insights for innovation and strategy. The ideal scenario would have a brand manager that could also be a Chief Culture Officer, i.e. capable of performing both an insightful analysis of consumer and cultural shifts, as well as the activation of strategies into successful actions and objects.

When approaching the skills and intervention areas of the CCO, it became clear that it was necessary to focus on cultural management emerging disciplines, from cultural analysis to trends studies. Although other fields, like design thinking and management could also be of great contribution, they would require a new full set of skills, concepts and knowledge. In order to focus the discussion on cultural management, they were not considered on this paper, which is a limitation of the conceptual reflection that can be developed in future research.

On the other hand, by understanding and applying coolhunting and trends studies to cultural analysis, we propose that it is possible to see emerging patterns and the new mindsets that are behind them. This transdisciplinary perspective articulates itself with the CCO profile and can give an edge to a company, allowing it to better understand its audiences and consumers, as well as to adapt and to remain competitive. This is one of the basis of this paper: to show the potential and benefit of articulating a solid background on cultural analysis and knowledge in strategy, marketing and, specifically, market research.

This paper aimed to add to the state of the art by working on the initial vision of Grant McCracken for the Chief Culture Officer, adding to this professional the skills associated to coolhunting and trends studies. This addition allows the CCO to better understand and prepare for cultural changes and it gives him a broader perspective on the zeitgeist. The paper also added to the discussion of the discipline of cultural management, taking it from the perspective of managing the cultural sector into a point where the study of culture can be applied to better business and brand strategies and practices. This brings the Humanities closer to the Business Sciences and to Social Sciences in general, and shows other potential for the study of culture.

This paper is presented as an introduction to the potential of cultural studies as a business and consumer analysis tool, working as a conceptual reflection based on literary review, which can serve as a basis for future ap- 
plied research and case studies. It is necessary to study in the future how to promote a professional like the Chief Culture Officer and how to train him properly for such activities. Also, it remains to explore in further research how the study of culture can be properly integrated into marketing and innovation departments and methodologies, adding to their practices and models, since we live a more liquid and fluid world that demands businesses to be prepared for cultural changes that affect consumer culture, both in needs and behaviors.

\section{REFERENCES}

ARNOULD, Eric J.; THOMPSON, Craig J. .Consumer Culture Theory (CCT):

Twenty Years of Research. Journal of Consumer Research, v. 31, n० 4, pp. 868-882, 2005.

ASKERGAARD, Soren; KJELDGAARD, Dannie. The Water Fish Swim In? Relations between Culture and Marketing in the Age of Globalization. Perspectives on Marketing Relationships, ed. Thorbjorn Knudsen, Soren Askegaard, and Niels Jorgensen, Copenhagen, 2002.

BAUMAN, Zygmunt. Ensaios sobre o conceito de Cultura. Translated by Carlos Alberto Medeiros. São Paulo: Zahar, 2012.

BAUMAN, Zygmunt. Liquid Modernity. Cambridge: Polity Press, 2000.

BOURDIEU, Pierre. A distinção: Critica Social do Julgamento. Translated by Daniela Kern and Guilherme F. Teixeira. São Paulo: Edições Zouk, (2006) [1979]. DADDI, Richard (2012). “A Case for the Chief Culture Officer". URL: http://headspacepartners.com/55/ (consulted on 17-12-2015)

DAWKINS, Richard. The selfish Gene. Oxford: Oxford University, 2006 [1976]. GOMES, Nelson Pinheiro. Trends Management applied to Branding and Cultural Management. E-Revista Logo, v.5, n¹, 2016.

GOMES, Nelson P.; FRANCISCO, Ana Filipa. Introdução aos Estudos de Tendências: Conceitos e Modelos. Lisbon: Trends Research Center, 2013.

HABERMAS, Jürgen. The Structural Transformation of the Public Sphere: An Inquiry into a Category of Bourgeois Society. Translated by Thomas Burger. Cambridge: MIT Press, 1991.

HEDING, Tilde, KNUDTZEN, Charlotte F.; BJERRE, Mogens. Brand Management: Research, theory and Practice. New York: Routledge, 2009.

HIGHAM, William. The Next Big Thing. London: Kogan Page, 2009.

HOLT, Douglas. How Brands Become Icons: The Principles of Cultural Branding. Boston: Harvard Business School Press, 2004. 
HOLT, Douglas; DOUGLAS, Cameron. Cultural Strategy: using innovative ideologies to build breakthrough brands. Oxford: Oxford University Press, 2010. MCCRACKEN, Grant. Chief Culture Officer. How to create a living, breathing corporation. New York: Basic Books, 2011 [2009].

MCCRACKEN, Grant. Culture and Consumption. New Approaches to the Symbolic Character of Consumer Goods and Actitivies. Indianapolis: Indiana University Press, 1988.

O'REILLY, Daragh. "Cultural Brands / Branding Culture” in Journal of Marketing Management, n²1, 2005.

RAYMOND, Martin. The Trend Forecaster's Handbook. London: Laurence King, 2010.

SASSATELI, Roberta. Consumer Culture: History, Theory and Politics. London: Sage, 2007.

SOLOMON, Michael. Consumer Behavior. 4th edition, New Jersey: Prentice Hall, 1999.

VEJLGAARD, Henrik. Anatomy of a Trend. New York: McGraw-Hill, 2008. 
Nelson Pinheiro Gomes is an assistant professor at the Culture and Communication Program - School of Arts and Humanities, University of Lisbon, acting as the co-coordinator of the Post-Graduate Diploma Courses in Trends Communication, as well as Creative Industries and Cultures. He is also responsible for the scientific coordination of the Trends Observer platform. With a research focus on the management of culture, specifically at the level of Trends Studies and Cultural Branding, he completed his PhD and Post-Doctorate in Culture and Communication (University of Lisbon), as well as an MA in Cultural Sciences, an MBA and several post-graduate certificates and diplomas on Fashion, Urban Policies and Economics, Coolhunting, European Policies, among others. He is also a researcher at ULICES (University of Lisbon Centre for English Studies).

Recebido em: 19/01/2017

Aceito em: 29/03/2017 